\title{
Implantação e manutenção da coleção de culturas de microorganismos do UniCEUB
}

\author{
Marcella Melo Vergne de Abreu ${ }^{1}$ \\ Valdi Lopes Tutunji ${ }^{2}$
}

\begin{abstract}
RESUMO - Coleções de cultura de microorganismos apresentam importante contribuição para a preservação, manutenção e suprimento de culturas autenticadas aos pesquisadores. Garantem também, um estrito controle de qualidade para a aquisição e depósito em seus bancos. O presente trabalho descreve a origem, funcionamento e o estado atual da Coleção de Culturas do UniCEUB, que foi estabelecida em 2003 no Laboratório de Microbiologia, Centro Universitário de Brasília, Brasil.
\end{abstract}

Palavras-chave: coleção de culturas, microorganismos.

\section{Implantation and maintenance of microbial culture collection in UniCEUB}

\begin{abstract}
The microbial culture collection centres play a significant role for the preservation, maintenance and supply of authentic cultures to researchers. They also ensure that the culture deposits are subjected to strict quality control prior to including in their acquisition. This article describes the origin, way of functioning and present state of the UniCEUB Culture Collection, which was established in 2003 at the Laboratory of Microbiology, Centro Universitário de Brasília, Brazil.
\end{abstract}

Key words: culture collection, microbial.

Relatório Final apresentado ao $2^{\circ}$ Programa de Iniciação Científica do UniCEUB - PIC.

${ }^{1}$ Biomédica (UniCEUB), pós-graduanda em Biotecnologia (UFLA).

${ }^{2}$ Biólogo e professor (UniCEUB), pós-graduado em Saúde Pública (ENSP-FIOCRUZ) 
O Brasil está definindo mecanismos para cumprir com as obrigações da Convenção sobre a Diversidade Biológica (BRASIL, 2000). A disponibilidade e o acesso à informação de qualidade são fundamentais para a tomada de decisões, viabilizando trabalhos colaborativos, através do processo de avaliação e participação da sociedade em geral (FAPESP, 2000; MICROMAN, 2003).

Com esta visão, as coleções de culturas têm atuado na integração da comunidade científica, explorando as competências existentes e desenvolvendo tecnologias inovadoras para coletar, gerenciar, integrar, analisar e compreender os diversos microorganismos.

Coleções de culturas são centros de conservação que tem a função de coletar organismos relevantes para estudos científicos e aplicações tecnológicas, tornandoos disponíveis para usuários interessados. A maneira mais eficaz de conservar microorganismos de importância econômica é a preservação em coleções. Assim, a preservação e manutenção das culturas devem ser feitas de forma a garantir sua sobrevivência, estabilidade e pureza durante períodos prolongados de tempo, conservando características genéticas e propriedades morfológicas/fisiológicas.

Saber como preservar culturas bacterianas e dispor de técnicas simples e eficientes para tanto se reveste da mais conspícua importância em qualquer laboratório onde se desenvolvem atividades de pesquisa. A importância de se preservarem culturas bacterianas advém da necessidade de se poder dispor do organismo ou espécime a qualquer momento, quer para fins experimentais, quer para trabalhos de rotina ou para atendimento a solicitações de outros pesquisadores, para fins didáticos, para estudos comparativos, etc (ROMEIRO, 1996).

Contudo, preservar o microrganismo vivo não é o bastante. É necessário que se preserve o organismo vivo, por período de tempo o mais longo possível e através de um método que não permita ou minimize a ocorrência de mutações ou de variabilidade que possam vir a refletir na patogenicidade, virulência ou características básicas da cultura original.

Considerando que a taxa de mutações espontâneas entre bactérias é sempre elevada, o uso de qualquer método que permita a multiplicação do isolamento, invariavelmente, envolve o risco de que ocorram mutações e aumento da probabilidade de alterações na sua estabilidade genética (ROMEIRO, 1996; DUARTE, 2003).

As atividades de rotina e pesquisa aplicadas às linhagens resultam em uma quantidade significativa de informações. A identificação microbiológica decorre, inicialmente, de provas bioquímicas, mas o uso de técnicas de biologia molecular, no futuro, pode enriquecer o conhecimento a esse respeito, trazendo um impacto significativo no nível de resolução taxonômica, na qualidade científica da pesquisa e na produtividade dos grupos de pesquisa, tornando-os competitivos em ní- 
vel internacional, além de possibilitar a solução dos problemas de classificação, relacionados à caracterização e à definição de novos táxons, em diversos grupos de microorganismos.

Existe um importante problema com a distribuição numérica desigual de diferentes táxons na natureza e o conseqüente favorecimento de grupos de organismos de crescimento rápido, melhor adaptado às condições de cultivo utilizadas nos procedimentos de isolamento (MANFIO, 2003).

Não dispomos de uma base de conhecimento suficiente para desenvolver uma estratégia que integre as questões sociais, ambientais e econômicas do país, nem podemos adotar estratégias que visem um levantamento integral da nossa biodiversidade. Temos que explorar as novas tecnologias e ferramentas que existem ou que estão sendo desenvolvidas, como a tecnologia de satélites, modelagem matemática, seqüenciamento genético, tecnologia de informação, tecnologia de comunicação, entre outras, caminhando na direção de construir a base de conhecimento necessária para desenvolver estratégias integradoras (CANHOS et al., 2004a; MOREIRA-FILHO, 2004).

Fatores que tem contribuído para a falta de conhecimento sobre a diversidade microbiana, em amostras ambientais, são em grande parte relacionados às limitações dos métodos tradicionalmente utilizados para o isolamento e condições de cultivo incompatíveis com as condições encontradas no ambiente natural dos microorganismos. A microbiologia clínica teve, historicamente, um maior avanço que a microbiologia ambiental devido a sua importância para a saúde pública no Brasil (MANFIO, 2003).

Coleções de referência de microorganismos têm sido apontadas como recursos importantes para o desenvolvimento de pesquisas em biodiversidade e sistemática. Um ponto crítico citado como limitante ao desenvolvimento da microbiologia ambiental no Brasil refere-se à falta de apoio às coleções de referência de microorganismos no país. Coleções científicas importantes, incluindo acervos de microalgas, protozoários, bactérias, fungos filamentosos, leveduras e linhagens celulares, são predominantemente localizadas nas regiões Sudeste e Sul, em centros de pesquisa e universidades, sendo que, regiões consideradas ricas em diversidade, como Norte (Amazônia) e Centro-Oeste (Cerrado/Pantanal/Mata Atlântica), apresentam um número pequeno de coleções (MANFIO, 2003).

A diversidade e taxonomia de diversos grupos de microorganismos ainda não são satisfatoriamente conhecidas e trabalhadas. Estudos indicam que ambientes tropicais podem apresentar regiões de megadiversidade onde, uma porcentagem das espécies é ainda desconhecida para a ciência. A diversidade microbiana, considerando-se a diversidade de espécies de arqueas, bactérias, vírus, protozoários e fungos suplanta, em número de táxons e variabilidade genética, a diversidade 
existente em todos os grupos de seres vivos em algumas ordens de magnitude. $\mathrm{O}$ número estimado de espécies de microrganismos no mundo gira em torno de 1.800.000, sendo que somente pouco mais de $2 \%$ deste total está sendo preservado em coleções de culturas (Guedes et al., 2004). A alternativa da conservação de microrganismos ex situ é uma garantia de acesso em longo prazo a eles (GOTTSCHAL et al., 2003).

Os microrganismos apresentam uma imensa diversidade genética e desempenham funções únicas e cruciais na manutenção de ecossistemas, como componentes fundamentais de cadeias alimentares e ciclos biogeoquímicos. Apesar de sua grande importância na manutenção da biosfera, estima-se que menos de 5\% dos microrganismos existentes no planeta tenham sido caracterizados e descritos (CANHOS et al., 2004b).

Os avanços em instrumentação, robótica, informatização e biologia molecular, associados às novas estratégias de screening e à grande diversidade microbiológica existente e inexplorada, deverão propiciar novas aplicações biotecnológicas destes microorganismos. Nos últimos anos, o estudo de bactérias patogênicas foi beneficiado por novos métodos como, o desenvolvimento de anticorpos monoclonais para as técnicas sorológicas. Técnicas baseadas na análise de ácidos nucléicos foram feitas e possibilitaram um estudo mais preciso da taxonomia e, um bom estudo dos fatores de controle da patogenicidade. Ao contrário dos métodos convencionais que contam com a reação de indução dos patógenos, essa emergente técnica tem enormes vantagens para caracterizar, identificar e detectar microorganismos baseado na informação genômica (DUVEILLER et al., 1997). As perspectivas de recuperação ambiental através de biorremediação e pesquisa em biossensores são bastante promissoras, porém, dependentes de novos isolados. Para o pleno desenvolvimento destas oportunidades, é fundamental que culturas puras e autenticadas estejam prontamente disponíveis para o desenvolvimento de projetos tecnológicos (CANHOS, 2004). Ainda, assim, o interesse na conservação desses recursos genéticos é baixo em relação ao papel que eles exercem na natureza e na sociedade.

O isolamento, identificação, seleção, caracterização, conservação e uso de microrganismos é prática imprescindível para o desenvolvimento de processos e obtenção de produtos de interesse econômico. A implantação e manutenção de coleções de culturas proporcionam estoques de linhagens nativas, que podem ser utilizadas em diversos programas de interesse da sociedade (GUEDES et al., 2004).

Características adicionais de um bom método de preservação seriam sua simplicidade, o não requerimento de equipamento sofisticado, baixo custo, rapidez de execução e, obviamente, elevado grau de eficiência. É desnecessário dizer 
que um método ideal de preservação, capaz de reunir todas as características e vantagens anteriormente citadas inexiste (ROMEIRO, 1996).

Teoricamente, para cada organismo, devido às suas peculiaridades intrínsecas, dever-se-ia desenvolver um método específico. Esta proposição, utópica a nível de laboratório, é contornada adotando-se alguns métodos de preservação, já testados e recomendados, úteis a certos grupos ou gêneros de microorganismos.

Patógenos são freqüentemente caracterizados pela condução de testes bioquímicos, sendo também possível identificá-los por sorologia ou técnicas moleculares. Poucos testes são geralmente suficientes para definir gêneros de microorganismos, porém cada um segue uma chave de identificação, sendo necessário um conjunto maior de provas para definir a espécie biológica.

Bactérias podem ser preservadas pelo cultivo periódico em diferentes meios, mas deve ser notado que sua sobrevivência decai em torno de 1-10 semanas e sua agressividade ou patogenicidade pode se alterar após sucessivas transferências (DUVEILLER et al., 1997).

As bactérias não podem ser identificadas com base somente em sua morfologia e, portanto, necessitam do uso apropriado de testes bioquímicos, fisiológicos ou de técnicas moleculares (DUVEILLER et al., 1997).

Para garantir a reprodução e continuidade dos processos de investigação biomédica, os cientistas encaram, hoje, a tarefa de estabilizar geneticamente as células. Subculturas seriadas consomem tempo e podem levar a contaminações ou tendem geneticamente a diminuir porções da população selecionada. No entanto, a população de células pode ser estabilizada, estando elas sujeitas a temperaturas criogênicas, parando o tempo. A estabilização de células a baixas temperaturas é chamada de criopreservação. Avanços científicos têm levado a métodos que permitem manter viável, em baixas temperaturas, diferentes tipos celulares. Técnicas são avaliadas para a preservação de microorganismos, células teciduais isoladas, pequenos organismos multicelulares e, alguns organismos mais complexos como, por exemplo, embriões (SIMIONE, 2004).

O processo de congelamento envolve complexos fenômenos que, depois de décadas de pesquisas, não foram totalmente compreendidos. Estudos criobiológicos têm levado a especulações sobre o que ocorre durante o congelamento de células vivas e como os fenômenos adversos podem ser vencidos. Sendo a água o componente vital das células e, fundamental para os processos bioquímicos, o metabolismo celular cessa quando a água de todo sistema é convertida em gelo (SIMIONE, 2004).

O método de preservação em glicerina, hoje universalmente usado em quase todos os laboratórios de Microbiologia e Bacteriologia do mundo, reúne quase 
todas as características desejáveis de um bom método de preservação (ROMEIRO, 1996).

Diversos fatores devem ser considerados quando se preparam células para criopreservação; dentre eles, o tipo de célula, sua viabilidade, condições de crescimento, estágio fisiológico, número de células e como elas são manuseadas. Quando se inicia a preparação de uma nova linhagem celular que será estocada, a cultura deve ser examinada para contaminação e ter a identificação do microorganismo. Esta análise deve ser repetida após o descongelamento e cada vez que um novo lote de cultura for preparado (SIMIONE, 2004).

O processo de crioproteção envolve diferentes passos. O primeiro é preparar as culturas para o congelamento. Para prevenir a desidratação, trabalha-se para que todos os fluidos celulares se solidificarem juntos. Isso pode evitar a alteração na concentração dos minerais e prevenir a formação de cristais de gelo e conseqüente ruptura da parede celular. Para tanto, agentes protetores do congelamento devem ser adotados. O glicerol é bioquimicamente compatível com as estruturas celulares e, portanto, freqüentemente usado para preservação. Desta forma as células podem ser preservadas por um tempo indefinido e recuperar suas funções normais quando forem devidamente descongeladas (BLACKMORE, 2004).

Em um processo de congelamento lento, as células apresentam perda de água. Quando os cristais de gelo se formam, eles se expandem e podem destruir a parede das células. Todo o material intracelular pode alterar a proporção ácido-base e causar extremo aumento dos seus níveis de concentração. Acelerando o processo de congelamento em que a temperatura é mensurada, sendo ideal o de-caimento de $1^{\circ} \mathrm{C}$ por minuto, alguns destes eventos destrutivos podem ser evitados. Cristais de gelo vão se formando dentro das células de maneira que ela vai perdendo água, e o tamanho dos cristais tendem a diminuir, reduzindo a destruição das paredes celulares (BLACKMORE, 2004).

As formas de gelo apresentam proporções diferentes durante o processo de congelamento. Um congelamento lento provoca a formação de cristais de gelo extracelulares mais rápido que intracelularmente. Visto que, a formação do gelo consome a água do meio extracelular, ocorre um desequilíbrio osmótico através da membrana celular, levando a migração de água para fora da célula. $\mathrm{O}$ aumento da concentração do soluto extracelular, e também intracelularmente, pode comprometer a sobrevivência da célula. Se muita água restar dentro da célula, a formação de cristais de gelo será danosa e durante o descongelamento pode ocorrer recristalização (SIMIONE, 2004).

A intensidade em que ocorre o congelamento é crucial neste fenômeno. Um rápido congelamento diminui os efeitos danosos das diferentes formações dos cristais de gelo, mas leva ao aumento da quantidade de gelo intracelular. Já o con- 
gelamento mais lento, resulta em grande perda de água pelas células e menos gelo interno, mas aumenta os efeitos do desequilíbrio osmótico. Quanto maior a permeabilidade celular, maior será a perda de água e, portanto, é mais provável que tolerem melhor o congelamento rápido que as células menos permeáveis. $\mathrm{O}$ uso de aditivos ou químicos crioprotetores, que servem para proteger as células durante o congelamento, pode diminuir os danos provocados pela concentração do soluto e pela formação dos cristais de gelo. Os agentes crioprotetores mais comumente usados são o DSMO (dimetilsulfóxido) e o glicerol (SIMIONE, 2004).

Os agentes crioprotetores assumem diversas funções no processo de congelamento. Estes agentes são mais efetivos quando podem penetrar a célula, atrasando o congelamento intracelular e diminuindo danosos efeitos osmóticos. A escolha do agente de crioproteção depende do tipo de célula que vai ser preservada. Para a maioria das células o glicerol é o agente de escolha porque, geralmente, é menos tóxico que o DSMO. Entretanto, o DSMO tem maior poder de penetração e, normalmente, é o agente de escolha para preservação de maiores e mais complexas células como, por exemplo, os protistas. A melhor forma de acrescentar o agente de proteção na suspensão de células é diluí-lo para a concentração desejada no meio fresco de crescimento prévio. Isso diminui os efeitos potencialmente deletérios das reações químicas que geram calor e, assegura uma exposição uniforme ao agente crioprotetor, quando adicionado à suspensão de células, reduzindo os efeitos tóxicos. A concentração ótima do agente de crioproteção varia de acordo com o tipo celular e o aumento da concentração de células pode tolerar seu uso. Para bactérias e leveduras recomenda-se o uso do glicerol 10\% como agente crioprotetor e a concentração celular equivalente a $10^{7} / \mathrm{ml}$ (SIMIONE, 2004).

Células microbianas, particularmente, bactérias e leveduras, crescem em condições aeróbias, demonstrando melhor resistência aos efeitos danosos do congelamento que as células não aeróbias. Pesquisadores demonstraram que a permeabilidade celular é maior em culturas aeróbias e que estas células desidratam mais rápido que as não aeróbias. Microorganismos demonstram maior resistência ao congelamento se não forem células muito jovens ou velhas, devendo estar preferencialmente no final da fase log ou início da fase estacionária de acordo com a curva de crescimento (SIMIONE, 2004).

Exposição prolongada aos agentes de proteção pode prejudicar/danificar as células, desse modo, o tempo de tratamento e a concentração do criopreservante é um fator importante para controle. O período de tempo entre a mistura do crioprotetor com a suspensão de células e o início do processo de congelamento é chamado de período de equilibração. Para a maioria das células, o período de equilibração é em torno de 15 minutos, não devendo ultrapassar 45-60 minutos. Isso porque o agente crioprotetor pode ser tóxico para as células se o tempo de 
equilibração for muito longo. Este processo deve ocorrer à temperatura ambiente, sob o abrigo da luz, considerando que as células mais permeáveis ficam expostas por um período menor que as células menos permeáveis, portanto, o tempo ótimo do processo de equilibração deve ser definido empiricamente (SIMIONE, 2004).

O terceiro estágio da criopreservação é o processo de descongelamento (rápido ou lento). $\mathrm{O}$ descongelamento rápido consiste em manter as culturas em banho-maria $25-40^{\circ} \mathrm{C}$ ou estufa bacteriológica $35-37^{\circ} \mathrm{C}$ por alguns minutos, até que os cristais de gelo se desfaçam, resultando em amostras de significante viabilidade. Este método tem a vantagem de minimizar o tempo de exposição a crioprotetores potencialmente citotóxicos. Logo em seguida, as culturas devem ser diluídas ou semeadas em um meio fresco para prevenir danos do crioprotetor e iniciar o reparo celular (SHORE, 2004).

Os fatores críticos na criopreservação englobam: o tipo de agente crioprotetor, sua concentração e, a duração do processo de congelamento (SHORE, 2004).

O sucesso do procedimento de criopreservação é mensurado com o uso de ensaios de viabilidade para quantificar a porcentagem de células que sobreviveram ao congelamento. A viabilidade e a estimativa de recuperação devem ser determinadas juntas, antes e depois do congelamento da cultura. Viabilidade é a capacidade de reprodução e crescimento das culturas. Na estimativa, o número de células recuperadas/hábeis deve ser avaliado de diferentes formas, incluindo diluições e contagem padrão em placa (SIMIONE, 2004). A comparação das contagens primárias e pós-congelamento indica a debilidade da recuperação ou o sucesso do procedimento de preservação. Alterações no número de células ou no seu comportamento indicam problemas ocorridos durante o armazenamento ou manuseio da amostra.

Para controlar todos os processo que envolvem o congelamento de culturas, é necessário que haja adequada documentação que indique, para cada amostra, a metodologia de congelamento/preservação adotada, a localização e identificação do material estocado, a data do congelamento e o número de repiques. Outros dados importantes são: o código da amostra congelada e seu lote, as provas de identificação e responsável, meios de armazenamento e também, a origem de cada amostra.

Assim, fica claro que uma coleção de culturas não é uma mera "colecionadora" de linhagens. Coleções de Culturas são centros de excelência, agindo como unidades de conservação ex situ, mantendo e estudando um pool genético para as gerações futuras, oferecendo serviços fundamentais para a comunidade científica e tecnológica.

A formação da coleção de culturas do UniCEUB demonstra a busca da qualificação científica das pesquisas através da construção e institucionalização 
de seu patrimônio científico como meio eficaz para garantir uma real autonomia que viabilize a realização, consolidação e expansão das pesquisas na instituição.

\section{Histórico no mundo}

Coleções de culturas tradicionalmente têm prestado serviços de apoio à comunidade microbiológica. A gama destes serviços tem aumentado muito nos últimos anos devido à crescente demanda por parte dos usuários.

Nos países em desenvolvimento, as coleções de culturas não têm merecido a devida atenção. Geralmente são consideradas subprodutos da pesquisa, em especial da pesquisa básica e sua manutenção e preservação são atribuições ou responsabilidades dos próprios investigadores. Nesses países, os empresários ignoram a importância dessas coleções como infra-estrutura relevante para a inovação tecnológica e para a produtividade industrial.

A Grã-Bretanha foi um dos primeiros países a reconhecer a necessidade de uma política nacional para a conservação de culturas microbianas. A Rede Britânica de Coleções de Culturas de Microrganismos originou-se de uma conferência de especialistas realizada em 1947, na qual se decidiu pelo estabelecimento, com recursos do governo, de um sistema descentralizado de coleções sediadas em diferentes instituições atuantes em áreas diversas de microbiologia básica e aplicada, composta por 11 coleções de serviços. Esta rede está sendo reorganizada de forma a reunir os vários repositórios sob a égide de uma única organização que deverá estabelecer uma estratégia de coordenação e marketing concentrando as atividades de serviço e acervos em quatro coleções principais: IMI (International Mycological Institute), NCIMB (National Collection of Industrial and Marine Bacteria Ltd.), ECACC (European Collection of Animal Cell Cultures) e CCAP (Culture Collection of Algae and Protozoa) (SMITH, 1998; NCIMB, 2003; WDCM, 2003).

Os Estados Unidos da América do Norte e a Alemanha possuem coleções centralizadas que oferecem um amplo espectro de atividades, incluindo curadoria, serviços e pesquisa, sob o mesmo teto. As vantagens deste modelo incluem:

- Economia de escala;

- Facilidade na organização, análise e troca de informações;

- Possibilidade de implementar sistemas integrados de boas práticas laboratoriais entre os diferentes departamentos;

- Possibilidade de se ter no mesmo local uma equipe altamente especializada.

Diferenças em ênfase quanto à dicotomia serviços/pesquisa marcaram a história 
do estabelecimento e desenvolvimento da ATCC (American Type Culture Collection) e da DSMZ (Deutsche Sammlung Von Mikroorganismen und Zellkulturen). A ATCC, fundada em 1925, funciona como organização privada, sem fins de lucro, e conta com um aporte substantivo de recursos do governo, tem um grande mercado doméstico e é considerada a gigante das coleções de culturas internacionais, tanto em termos de receita e orçamento, como também em seu escopo de atividades.

A DSMZ foi estabelecida em 1969 como um sistema federativo de coleções com um gerenciamento centralizado. Foi reunificada, e o acervo foi transferido para um mesmo edifício no final da década de 80. Desde o seu estabelecimento, a DSMZ sempre teve uma forte orientação acadêmica, voltada para a sistemática e taxonomia. Embora a DSMZ seja atualmente uma empresa, ainda mantém muito do caráter de instituição de pesquisa, sendo dirigida por um taxonomista de renome internacional.

\section{Histórico no Brasil}

No Brasil, na maioria dos casos, as coleções decorrem da iniciativa dos pesquisadores, com manutenção por vezes amadora e precária, algumas inclusive, ameaçadas de desaparecimento, devido ao afastamento de seus responsáveis, pois não existe a desejada institucionalização. As coleções de cultura, em geral, não dispõem sequer do mínimo indispensável para sua manutenção em condições satisfatórias para atender a demanda de um país em franco desenvolvimento (Canhos, 1994).

No passado, quando se desejava trabalhar com pesquisa em que havia necessidade de culturas puras de um determinado patógeno, era necessário recorrer a coleções do exterior. Isso, não só demandava uma perda desnecessária de tempo, às vezes extremamente longo, como também, freqüentemente eram recebidas culturas com características diferentes daquelas predominantes em nosso meio. A existência de uma coleção sanaria essas dificuldades e permitiria a cooperação no atendimento a solicitações para trabalhos de pesquisa e ensino. Essa foi a idéia que deu origem às coleções existentes no Brasil (FIGUEIREDO, 2001).

Ao longo dos últimos 50 anos, trabalhos sobre ecologia microbiana vêm sendo realizados nos institutos de pesquisa, principalmente, no estado de São Paulo. Além dos trabalhos pioneiros realizados no Instituto Agronômico de Campinas a partir da década de 40, inúmeros trabalhos foram realizados por pesquisadores do Instituto de Botânica e Escola Superior de Agricultura Luís de Queiroz. Muitos dos trabalhos abordavam a ecologia e sistemática de microorganismos de relevância agrícola, relacionados a doenças de plantas de interesse econômico. A 
partir da década de 70, vários trabalhos associados a cursos e programas de pósgraduação foram desenvolvidos nas universidades, como por exemplo, USP, UNICAMP e UNESP (FAPESP, 2000).

Uma grande referência em tecnologia e pesquisa, a EMBRAPA é uma empresa brasileira com reconhecimento internacional, que enfatiza pesquisa em diferentes temas, produtos e ecossistemas, aliando agricultura, pecuária, agroindústria e meio ambiente, desenvolvendo novas tecnologias de produção. Mantém coleções de culturas diversas, como bactérias diazotróficas, fungos de interesse no controle biológico, microorganismos fixadores de nitrogênio, dentre outras.

O país dispõe de coleções de referência, que vem se desenvolvendo continuamente como a Coleção de Culturas Tropicais (CCT) da Fundação Tropical de Pesquisas e Tecnologia André Tosello - Campinas/SP; Coleção de Culturas IBSBF do Instituto Biológico - Campinas/SP; Coleção de Culturas da Fundação Oswaldo Cruz - Rio de Janeiro/RJ; Coleção de Culturas do Instituto Adolfo Lutz - São Paulo/ $\mathrm{SP}$, dentre algumas outras. Ainda há muito a ser desenvolvido no Brasil, tendo em vista a vasta biodiversidade dos diferentes ecossistemas nele contido (BDT, 2003; FAT, 2003; INSTITUTO BIOLÓGICO, 2003; SICOL, 2003).

\section{Objetivo}

Desenvolver a metodologia relacionada à conservação de isolados bacterianos e fúngicos a baixa temperatura, que permita a preservação e fornecimento de culturas de microorganismos para fins de pesquisa e ensino.

\section{Relevância Científica}

Preservando e disponibilizando um acervo microbiológico significativo, permite:

- Despertar o interesse pela biodiversidade e desenvolvimento sustentável;

- Incentivar a pesquisa para novas aplicações biotecnológicas;

- Expandir o potencial de uso dos recursos microbianos nas áreas: industrial, agropecuária, de tecnologia de alimentos, saúde, economia e ambiental.

\section{Relevância Didático-Pedagógica}


Voltada ao atendimento da demanda acadêmica para fins didáticos, fornecendo microrganismos específicos, para o desenvolvimento de aulas, teses e projetos de pesquisa, permite:

- Implementar sistemas de boas práticas laboratoriais interdisciplinares;

- Demonstrar, os mecanismos fisiológicos, bioquímicos e moleculares pelos quais a maior parte dos microorganismos pode ser isolada e identificada no laboratório.

- Divulgar a qualidade científica do UniCEUB.

\section{Mateniais e Métodos}

Não existe ainda um consenso quanto à metodologia para a conservação de amostras microbiológicas. Numerosas técnicas já foram sugeridas e são utilizadas. No Laboratório de Microbiologia UniCEUB/FACS foram estabelecidos procedimentos que vem apresentando resultados satisfatórios .

As linhagens do acervo proposto a serem preservadas no LABOCIEN Laboratório de Microbiologia - UniCEUB/FACS, serão isoladas a partir de amostras biológicas, bem como, por outras fontes, direcionando esta coleção às áreas de saúde humana e animal com interfaces nas questões ligadas ao meio ambiente. Sua manutenção está relacionada aos meios de crescimento, temperatura e condições de incubação dos microorganismos.

As amostras podem ser originárias de doações, trocas, aquisições de outras coleções, coletadas, isoladas e identificadas no Laboratório de Microbiologia do UniCEUB. Pela rotina do laboratório o uso de meios seletivos direciona a busca por microorganismos específicos que sejam de interesse para a coleção.

Foram analisadas 1500 amostras de diversas espécies bacterianas e fúngicas, quanto a viabilidade sob baixa temperatura $\left(-20^{\circ} \mathrm{C}\right)$, a fim de estabelecer uma metodologia eficaz e viável de criopreservação. Essas análises basearam-se na comparação da viabilidade do inóculo bacteriano antes e após o período de congelamento, em diferentes meios de cultura e agentes crioprotetores, segundo Blackmore (1996) e Simione (1998).

Aliado a outros achados na literatura, essas análises possibilitaram o desenvolvimento de uma documentação orientadora dos procedimentos necessários à implantação e manutenção da coleção de microorganismos (Procedimento Operacional Padrão).

\section{Resultados e Discussão}


Foram coletas 1500 amostras distribuídas entre as seguintes espécies: Escherichia coli, Enterococcus sp., Staphylococcus sp., Aeromonas sp., Xanthomonas campestris, Candida sp. e Salmonella sp. que apresentaram graus de viabilidade diversos após períodos variáveis de criopreservação em diferentes meios de cultura e agentes crioprotetores.

De acordo com nossas observações, a temperatura de $-20^{\circ} \mathrm{C}$ é adequada para a maior parte dos microorganismos, porém, algumas células são sensíveis e não sobrevivem a longos períodos.

Quando descongeladas, boa parte das amostras apresentaram-se contaminada e a forma de armazenamento foi apontada como a potencial fonte da contaminação. Neste caso, as alterações ocorridas na temperatura do freezer foram significativas, uma vez que, seu aumento pode ter gerado descongelamento seguido de recristalização, causando danos na membrana celular, como também, o extravasamento de algumas amostras.

Segundo a literatura, a temperatura e o tempo de incubação durante o isolamento secundário influenciam o congelamento. Nossos achados confirmam essa informação.

Além disso, a limpeza e esterilização de vidrarias e meios de cultura são cruciais para todos os procedimentos internos do laboratório, interferindo no isolamento, identificação, congelamento das amostras e deve ser seguida criteriosamente.

Em relação à viabilidade das amostras, como demonstrado por Romeiro (1996), alguns autores adotam como rotina a preservação de E. coli em glicerina à $-20^{\circ} \mathrm{C}$, afirmando manter a viabilidade de suas culturas por vários anos. A maioria das amostras submetidas ao processo de congelamento desde dezembro de 2002 mantiveram-se viáveis no primeiro ano, principalmente, Escherichia e Enterococcus.

Amostras de Candida não apresentam bons resultados. Muitas colônias tornam-se atípicas, não reativas às provas bioquímicas ou simplesmente não cresceram, demonstrando que o processo de congelamento foi prejudicial.

\section{Conclusão}


A criopreservação $\left(-20^{\circ} \mathrm{C}\right)$ é viável para o congelamento de bactérias, mas não recomendada para leveduras devido ao alto grau de decaimento na viabilidade. Algumas limitações na estrutura laboratorial podem comprometer a manutenção da coleção de culturas como, por exemplo, a instabilidade da rede elétrica, que prejudicam o funcionamento do freezer, geladeira e estufa.

Para o congelamento, os microorganismos apresentaram bom comportamento na presença do agente crioprotetor (glicerol 10\%), mas excesso de manipulação dos eppendorfs pode gerar fontes de contaminação.

A manutenção de replicatas/lotes de cada amostra é fundamental e amplia a capacidade de conservação da metodologia adotada, diminuindo os risco de alterações morfofisiológicas, genéticas e moleculares, pela ocorrência de mutações e lesões na estrutura do microorganismo, que se acumulam ao longo de sucessivas gerações.

Sabe-se que muitos microrganismos não toleram mudanças muito bruscas de temperatura e que certos intervalos de $0^{\circ} \mathrm{Ce}-15^{\circ} \mathrm{C}$ têm sido reconhecidos como críticos ou letais. Para manter a viabilidade de alguns microrganismos parece mais conveniente congelar tendo o decréscimo de $1{ }^{\circ} \mathrm{C}$ por minuto e descongelar rapidamente, evitando a exposição excessiva agente crioprotetor. Não existe um único meio adequado para o cultivo de todos os microorganismos, mas alguns são apropriados para um grande número deles, que não apresentem exigências especiais.

Os eppendorfs passaram a ser estocados em suportes de maneira que permaneçam em posição vertical por todo período de congelamento, diminuindo assim, os riscos de extravasamento e contaminação das amostras.

Para minimizar os problemas que envolvem todos os processos para criação e manutenção da coleção de culturas de microorganismos do UniCEUB, foi elaborado o POP - Procedimento Operacional Padrão que define as formas de condução das práticas laboratoriais.

\section{Referências}

BDT - Bases de Dados Tropical. Lista de Culturas Bacterianas (IBSBF). Disponível em: <http://www.bdt.fat.org.br/ibsbf/info>. Acesso em 12 mar.2003.

BLACKMORE, A. Bacteria on Ice. Lab Repot, 1996. Disponível em: <http://vcsf.us/ Student\%20Sample\%20Project\%20Cryogenics.pdf>. Acesso em: 03 mar. 2004.

BRASIL. Ministério do Meio Ambiente. Secretaria de Biodiversidades e Florestas. A Convenção sobre a Diversi-dade Biológica. Brasília, DF, 2000.

CANHOS, D. A. L.; CRESPO, S.; MANZOCHI, L.; PALERMO, A. P.; TAMAIO, I.; 
CARVALHO, I. C. M.; SOUZA, L.; VARELLA, M. D.; NASCIMENTO, N. P.; NOGUEIRA, N.; ALBAGLI, S. Estratégia Nacional de Diversidade Biológica. Grupo de trabalho temático: Educação, Conscientização Pública e Intercâmbio de Informações. Disponível em: <http://www.bdt.fat.org.br/publicacoes/politica/gtt/ gttedu/>. Acesso em: 02 fev. 2004a.

CANHOS, V. P. Estudo da Diversidade Microbiana: Bactérias, Fungos Filamentosos e Leveduras do Estado de São Paulo. Disponível em: <http://www.biota.org.br/info/ historico/workshop/revisoes/micro.pdf>. Acesso em: 02 fev. 2004.

CANHOS, V. P.; COUTINHO, H. L. C.; VAZOLLER, R.; RUMJANEK, N.; ROSADO, A.; BARROS, E.; AZEVEDO, J. L.; PELLIZARI, V.; MOREIRA, F.; SIQUEIRA, J. O.; MORAIS, G.; SCHENBERG, A. C. Estratégia Nacional de Diversidade Biológica. Microorganismos e Biodiversidade de solos. Disponível em: <http:// www.bdt.fat.org.br/publicacoes/politica/gtt/gtt10>. Acesso em: 02 fev. 2004b.

CANHOS, V.P. Views of Developing Country. The Biodiversity of Microorganisms and the Role of Microbial Resource Centers. Eds. B. Kirsop e D. L. Hawksworth. World Federation for culture Collections, 1994. p 45-52.

CLESCERI, L.S. EATON, A. D. GREENBERG, A. E. Standard Methods for Examination of Water and Wastewater. $20^{\mathrm{a}} \mathrm{ed}$, Ed. American Public Health Association, American Water Works Association e Water Environment Federation, Washington, DC, 1998. 1220 p.

DUARTE, V. Preservação de Culturas Bacterianas. Disponível em: <http://www.ufrgs.br/ agro/fitossan/fit35/ppreserva.htm>. Acesso em: 27 abr. 2003.

DUVEILLER, E., FUCIKOVSKY, L., RUDOLPH, K. The Bacterial Diseases of Wheat: Concepts and Methods of Disease Management In: DUVEILLER, E. BRAGARD, C. RUDOLPH, K. FUCIKOVSKY, L. General Concepts and Methods for the identification of Pathogenic Bacteria of Wheat. México, 1997. 5-23p.

\FAPESP - Fundação de Amparo a Pesquisa do Estado de São Paulo. Sistema de Informação Distribuído para Coleções Biológicas: A Integração do Species Analyst e SinBiota. Disponível em: <http://splink.cria.org.br/docs/ProjetoPesquisaSpLinkFapes

p.doc>. Acesso em: 15 abr. 2003.

FAT - Fundação Tropical de Pesquisa e Tecnologia André Tosello. Coleções de Culturas Tropicais (CCT). Disponível em: <http://www.cct.org.br>. Acesso em: 31 mar. 2003.

FIGUEIREDO, M. B. Métodos de Preservação de Fungos Patogênicos. Palestra apresentada no III Congresso Brasileiro de Micologia. Sociedade Brasileira de Micologia, de 19 a 23 de agosto de 2001. Águas de Lindóia, SP. Biológico, São Paulo, v. 63, n 1/2 ,p 59-68. 2001.

GOTTSCHAL, J. C.; HARDER, W.; PRINS, R. A. Principles of Enrichment, Isolation, Cultivation and Preservation of Bacteria. Disponível em: <http:// microimm.queensu.ca/micr433/Enrichment\%20.pdf>. Acesso em: 10 abr. 2003.

GUEDES, A. C.; GOEDERT, C. O.; BUSTAMANTE, P. G.; MOREIRA, J. R. A.; MARIANTE, A. S.; WALTER, B. M. T.; BRANDÃO, C. R. F.; PROENÇA, C. E. 
B.; MUNHOZ, C. B. R.; MAGALHÃES, C.; SILVA, G. P.; COLLI, G. R.; BRANCHETTI, L.; MENDES, M. S.; VEIGA, R.; MENDONÇA, R. C.; SILVA, S. R.; CAVALCANTI, T. B.; PEREIRA, T. S. Estratégia Nacional de Diversidade Biológica. Conservação ex situ. Disponível em: <http://www.bdt.fat.org.br/ publicacoes/politica/gtt/gtt3>. Acesso em: 02 fev. 2004.

INSTITUTO BIOLÓGICO. Coleção de Culturas do Laboratório de Bacteriologia Vegetal IBSBF. Disponível em: 〈http://www.cria.org.br/ibsbf〉. Acesso em: 24 abr. 2003.

MANFIO, G. P. Avaliação do Estado Atual do Conhecimento sobre a Di-versidade Microbiana no Brasil. Projeto Estratégia Nacional de Diversidade Biológica. Ministério do Meio Ambiente. Secretaria de Biodiversidade e Florestas, Diretoria de Conservação da Biodiversidade. Campinas, SP, 2003.

MICROMAN - Microbial Management System. Culture Collection Man-agement. Disponível em: http://labis.biotec.or.th/microman/menu2/manual/appx1/appx1fram.html.

Acesso em: 12 mar. 2003.

MOREIRA-FILHO, C.A. Infra-estrutura Científica e Tecnológica: Coleções de Culturas de Microorganismos. Biodiversity: Perspectives and Technological Opportunities. Disponível em: <http://www.bdt.fat.org.br/publicacoes/padct/bio/cap8>. Acesso em: 02 fev. 2004.

NCIMB - National Collections of Industrial, Food and Marine Bacteria. Policy on Access to Genetic Resources and Benefit Sharing. Disponível em: <http://www.ncimb.co.uk/ Files/CBDinc/QF106.pdf>. Acesso em: 07 mai. 2003.

ROMEIRO, R. S. Preservação de Culturas de Bactérias Fitopatogênicas. Mimeografado. Universidade Federal de Viçosa. Departamento de Fitopatologia - UFV. Viçosa, MG. 1996. 11p.

SHORE, K. A., RADWAY, J. Optimizing Cryopreservation Protocols for the Hawaii Culture Collection. MarBEC - Marine Bioproducts Engineering Center, 2000. Disponível em: 〈https://www.marbec.org/education/projects/2000/report_shore.pdf $>$. Acesso em: 03 mar. 2004.

SICOL - Sistema de informação de Coleções de Interesse Biotecnológico. Coleção de Culturas Oswaldo Cruz. Disponível em: <http://sicol.cria.org.br/reunião_maio/ppt/ INCQ.ppt>. Acesso em: 20 mar. 2003.

SIMIONE, F. P. Cryopreservation Manual. Nalge Nunc International Coorp, 1998. Disponível em: <http://nalgenelab.nalgenunc.com/techdata/technical/

cryo.pdf>. Acesso em: 03 mar. 2004.

SMITH, D. Qual-ity Manual: UK New Strategy for Microbial Collections. Ed. United Kingdom National Culture Collection (UKNCC), Londres, 1998.

WDCM - World Data Centre for Microorganisms. Culture Colletions in the World. Disponível em: <http://wdcm.nig.ac.jp/hpcc.html>. Acesso em: 15 jan. 2003. 